\title{
LUT
}

Lappeenranta

University of Technology

\section{Digital learning design: from ideation via TRIZ to implementation}

\author{
Shnai Iuliia
}

This is a Author's accepted manuscript (AAM) version of a publication published by Springer, Cham

in Advances and Impacts of the Theory of Inventive Problem Solving

DOI: 10.1007/978-3-319-96532-1_1

Copyright of the original publication: (C) Springer Nature Switzerland AG 2018

Please cite the publication as follows:

Shnai I. (2018) Digital Learning Design: From Ideation via TRIZ to Implementation. In: Koziołek S., Chechurin L., Collan M. (eds) Advances and Impacts of the Theory of Inventive Problem Solving. Springer, Cham 


\title{
Digital learning design: from ideation via TRIZ to implementation
}

\author{
Iuliia Shnai
}

School of Business and Management, Lappeenranta University of Technology, Lappeenranta 53851, Finland

\begin{abstract}
Current digital medium influences on traditional higher education arrangement. Innovative standards, pedagogical methods, mechanisms for evaluations emerge driven by technology. In response to this changes, teachers adapt and embed creative course designs and invent new classrooms, attempting increase in effectiveness of education. This study is an attempt to apply systematic creativity toolkit for generation of ideas in higher education. The prime aim is to create concepts of completely new or enhanced educational course designs and methodologies. Theory of Inventive Problem Solving is defined package of idea generation tools, commonly applied for engineering. However, in this paper its value is recognized for ideation in general and applied to education. To achieve this aim the case-study was placed. The preliminary results provide conceptual models and ideas for new more effective knowledge, experience and attitude transfer forms. Each design is described in terms of Technological Pedagogical Content Knowledge (TPCK) model. TPCK is a basic framework for effective technology integration in teaching process. Some ideas appear in the real "Systematic Creativity and TRIZ" course in Lappeenranta University of Technology. The feedback system and video materials were developed and e-learning platform was selected for the course. Students' satisfaction and design effectiveness were tested by the surveys, observations and learning analytics from platforms. Overall, this work sheds light on the new blended and online learning designs and standards, underlining the necessity and direction of inventing and improving in higher education.
\end{abstract}

Keywords Higher education, Conceptual design, Learning design, TRIZ, Flipped classroom

\section{Introduction}

The worldwide digital shift influences the majority of the spheres, including education. Information consumption and delivery are realized in fast, flexible, constant, innovative forms. Lifelong learning is not anymore an option, it is a rooted style of doing things. Cultural shift has happened, moving our minds toward self- and guided- learning. Employees expect their future workers to be prepared, even if the person does not obtain the required knowledge and skills in the education institution. In their turn, job seekers are ready to study by themselves to satisfy the expectations of the company. Within the described environment, the place of the third stakeholder, mainly university and other education institutions which teach students in a traditional manner, become unsteady and questionable. 
To meet the needs of "YouTube age" learners, ways of knowledge and experience delivery in education undergoes alterations. Traditional learning approaches transit to blended or e-learning, forming innovative standards, methodologies and culture in education. Blended learning means that percent of the class is delivered digitally. Entirely online classrooms deliver all the content virtually. The virtual or partly virtual courses vary significantly from face-to face experience and require specific design to get the same or improved learning outcomes. The role of course designers is primarily accomplished by the teachers, researchers in the field of education, or instructional designers. One of the examples of blended learning designs is flipped classroom. Jonathan Bergmann and Aaron Sams coined the term flipped classroom in 2012 [1]. It is a reverted to traditional form of teaching, where the lecturing part is distilled in the form of video before the class, whereas in class time is devoted to activities [1].

Successful conceptual design is a first step toward innovation in design [2], therefore to approach the invention of new classroom designs creatively, the systematic-creativity tool was used. The provided case study is aimed to thoroughly investigate TRIZ ideas generation in the educational field to find ideas of new or improved classroom design types. Prime research question is: "How TRIZ can be helpful in ideas generation for new classroom development?" Additional research questions are "How these ideas respond to the TPCK education theory?", " How the concepts can be implemented and evaluated and "What are the basic results of their implementation?".

Theory of Inventive Problem Solving (TRIZ) is a systematic creativity tool, aimed to idea generation. Defined concept of creative thinking rooted in the work ofGenrich Altschulller in1956 [3] and the term appeared in $80^{\text {th }}$. The homecourt of TRIZ is Mechanical design [4] and currently it dominates in reports on the applications of the method.

The chapter adds to the use of TRIZ for education design. It focuses on the teaching classroom design concepts development. Idea generations for classroom designs requires justification in terms of educational effectiveness. Thus, the developed concepts are described in terms of Technological Pedagogical Content Knowledge (TPCK) framework. Some of ideas are implemented within course of "Systematic Creativity and TRIZ basics" at Lappeenranta University of Technology and the feedback of participants and data from learning management systems and video hosts are used as experiment results.

\section{Background}

Let us first briefly tell what is inside of TRIZ. The term "theory" is not really applicable to this collection of tools to stimulate the design of new concepts. These tools are non-uniform, overlap, need proper application of Occam razor as well as evidence based proofs of efficiency and scientific discussion. However, comparing to other competitors in the market of creativity support, it seems to be much closer to its name. In addition to extremely positive response from the practice, it has specific features of a theory: modelling techniques, the formalism over the models and a number of criteria to compare ideas. For example, TRIZ can model a situation that requires an inventive idea by contradictions. Having formulated the contradiction in generalized from one can get from TRIZ a number of principles to eliminate it or to change the design in such a way that conflicting requirements are separated. This is 
fundamental difference to natural intention of designer to commit a compromise. If ideation yielded several design ideas, there are reasonable fitness axioms to compare them like Ideality or Dynamization increase concepts. .

One of the modern TRIZ modelling tools is Function analysis. It presents a system as a number of interconnected elements, linked to each other by functions. Function between two components is legitimate if components are material objects, which interact and parameter of the Function recipient is maintained or changed as the result of function [11], where Function Recipient is an affected component. Having modelled a system by Function model (that sometimes need even research efforts) one can apply Trimming tool to reduce its complexity or Contradictions elimination tool in case harmful functions also detected in the model. Trimming is generally used for elimination of the elements within 3 main rules: elements which are not necessary, which can be substituted or which function, can be delegated to other elements [11]. Contradiction elimination by TRIZ is assessment of two isolated requirements, where one is an improving parameter and another is worsening. Ideal Final Result is a core concept of TRIZ, leading to more radical and creative ideas than others, since the invention with IFR can be realized without functional model. The formulation is "Ideal system is no system but the function is performed when it is necessary and where it is necessary" [11].

Therefore, there are two approaches for conceptual design of something new by TRIZ. First, approach is to start from the scratch and to generate ideas for new design. It means that there are only recommendations, specification and requirements to be met by the new design. Something completely new is to be invented. Regarding the classroom design, for example. the inventive ideas can be generated with IFR (Fig.1). The second approach departs from a functional model of the prototype system and TRIZ is applied to modify already existing design. Function models comprise basic tradition classroom and flipped classroom. Contradictions elimination is used for both models. Trimming is applied only for flipped classroom improvement (Fig. $1)$.

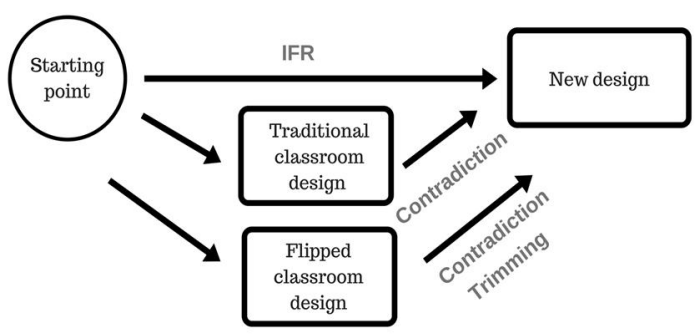

Fig. 1. Two approaches for conceptual design via TRIZ

The term "Learning design" refer to the modeling learning experience. Learning science combines different fields among which are education, computer science, design science, neuroscience [11], systems engineering, conceptual design and others. One of the standard and generally accepted by educational institutions designs is traditional classroom, where passive in-class lecturing plays a main role. Sometimes it is combined with or followed by face-to-face exercises, laboratories, discussion and other types of activities, however activities are generally moved to the homework. As blended and online learning (e-learning) concepts came to the stage quite recently, their designs vary significantly, their forms, standards and guidelines are the subject of intensive discussion. One of the described blended learning designs 
is flipped classroom, where the class time is devoted to the activities and the lecturing part is moved outside the class in the video form [5].

Extended by technology Shulman's conceptual model of "pedagogical content knowledge" frameworks the representation and justification of educational designs [6]. Historically, teaching was focused only on pedagogical and content knowledge and pedagogical content knowledge (PCK) as an interaction of them [7]. Mishra and Koehler extend Shulman's theory by technologies, based on the 5-year design experiments [6].

Each part of the technological content pedagogical knowledge framework defines and testifies the elements of teaching process and interactions between them (Fig. 2.). Content knowledge relates to the teaching subject whereas, pedagogy is a knowledge about processes and methodologies. C-P interaction is a harmonized method for teaching specific materials or "teaching approaches that fit content". Technology knowledge is the information on existing tools and solutions and their implementation. Technological content knowledge include primarily representation tools for the specific content. Technological pedagogical knowledge represents the teaching settings. TPCK is an interaction between three components [6].

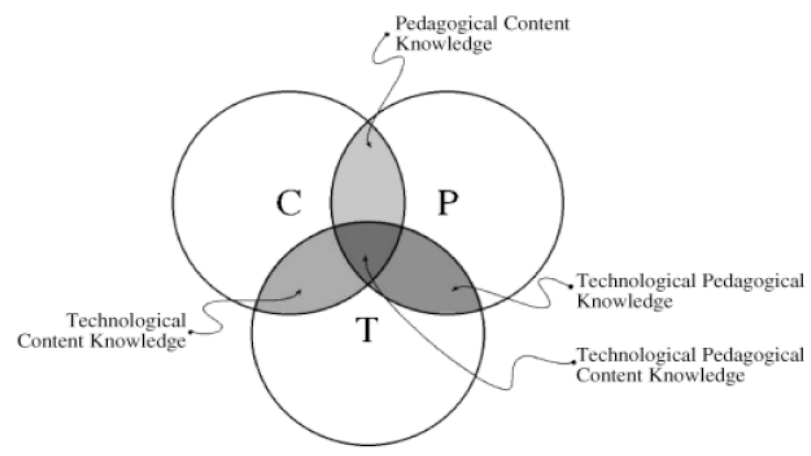

Fig 2. TPCK model (Mishra.P, J. Koehler (2006)

\section{Methods}

We address the research questions by the case study research, in which Contradiction analysis, IFR, Function modelling and Trimming are used for the generation of ideas and concepts for innovative learning design. Most of generated concepts are given the field text in the course on Systematic Creativity and TRIZ basics in Lappeenranta University of Technology. The surveys and observations are collected and analyzed to quantify the evaluation of new learning design.

Thus, the case study consists of 3 main steps :

1. Ideas generation via TRIZ (Function definition, Function modelling, Trimming, IFR, Contradictions Elimination)

2. Ideas evaluation via TPCK model

3. Ideas justification within real course design experiments 


\section{Case study: Conceptual learning design generation via TRIZ}

\subsection{Function definition and modelling}

Formulation of function for the "learning design" straight depends on the definition of the core competences. For instance, in Lappeenranta University of Technology the core competencies are skills, experience and attitude. Therefore, the function is to transfer knowledge to students, develop skills and attitude. The function is the same for any type of teaching classroom, including traditional classroom, flipped classroom, virtual classroom or any other combination of teaching units. According to that, the component model (Fig. 3) is going to have 4 level hierarchy, where on the first level is any learning design, on the second knowledge transfer part, and skills delivery part. More specific components are on the third and fourth level. The standard teaching elements are lectures and different types of activities, including seminars, laboratories, group works and etc. Primary function of the lecture is to deliver a knowledge, whereas seminars and activities are aimed to develop student's skills.

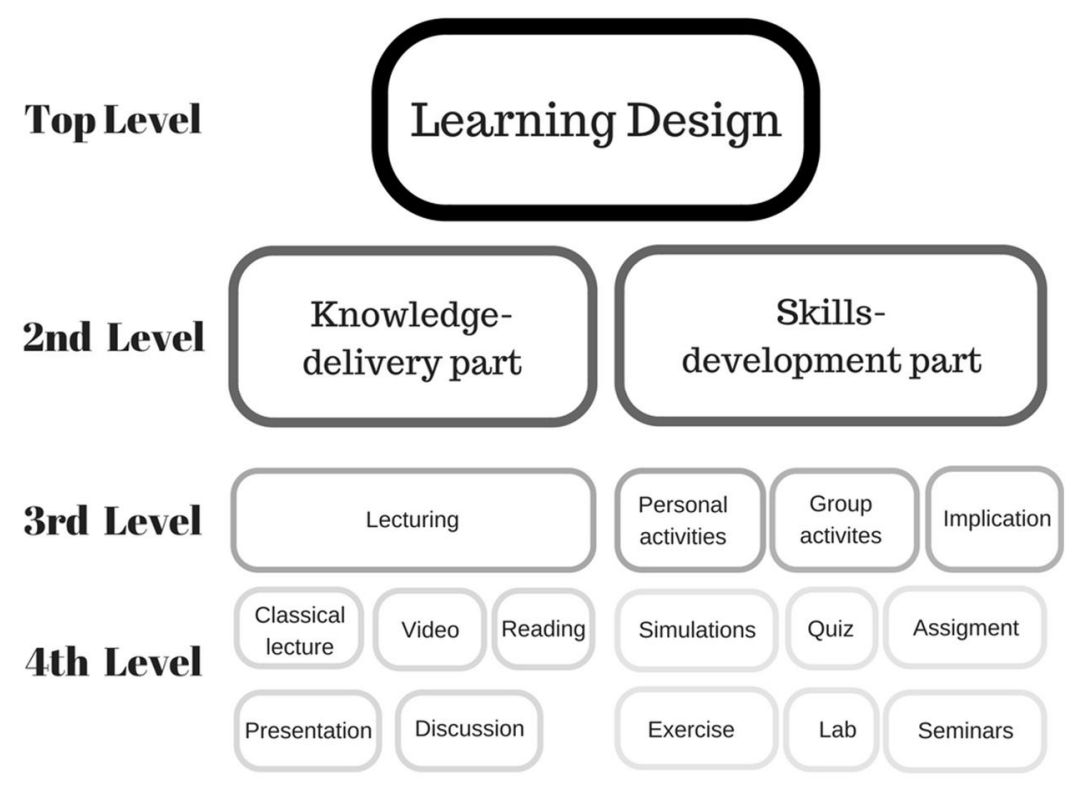

Fig 3. Component model of learning design

A simplified process flowchart for traditional learning class, flipped class and virtual one are described in the (Fig. 4). The two main functions mentioned on each class design for each component.

Knowledge transfer is followed by the skills transfer in each case. 


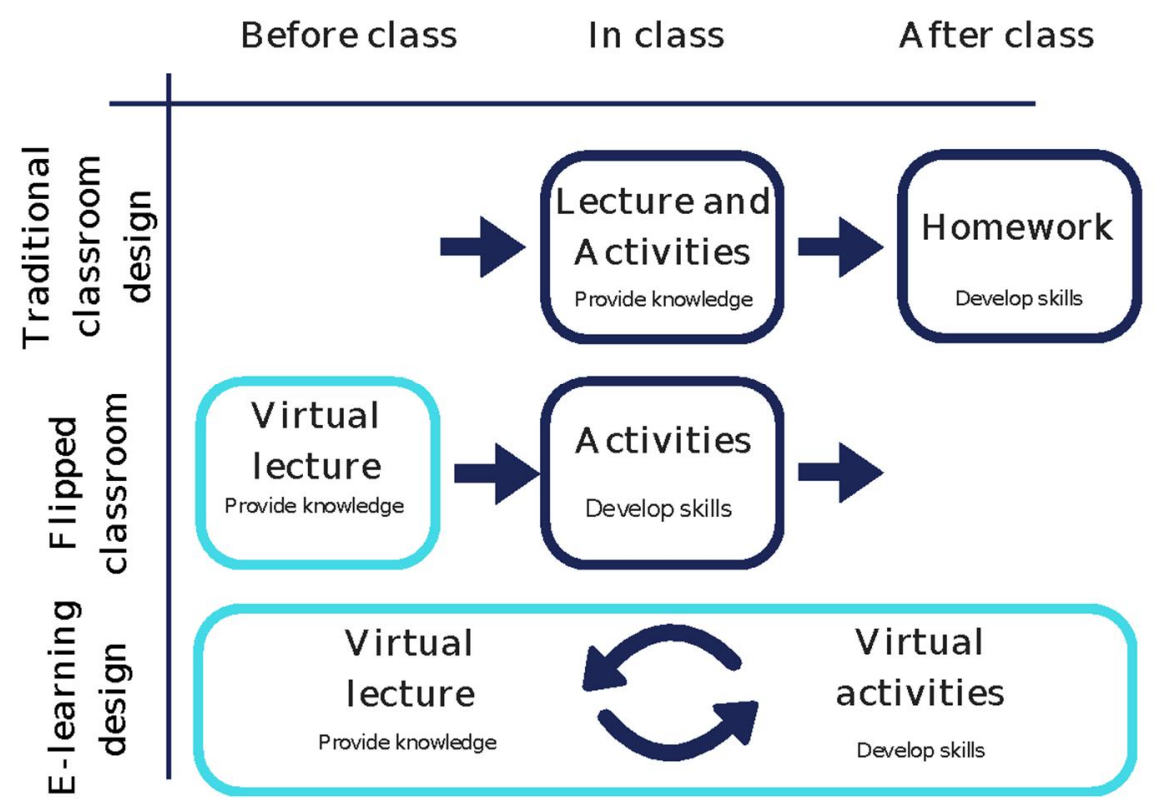

Fig 4. Basic learning process concepts for traditional flipped and online classroom

\subsection{Trimming}

Starting from functional model of the teaching classroom design, the system can be simplified by TRIZ trimming exercise. It yielded a model with complete lecture elimination. In the case of flipped classroom, traditional guided online or offline lecture disappears. Instead, guidelines and requirements are formulated by teacher for activity preparation. According to trimming rule, that says that a function carrier can be trimmed if another component performs its useful function, the knowledge transfer in this case can be accomplished by students' self-study with selection and learning process guided by students (Table 2).

In the age of increased amount of information, learners can find a lot of valuable, high quality content for the defined topic. Whereas, the limitation by the personalised teacher's lectures and books seem impossible. For instance, if the basic course of math is already taught by some other teacher in open source and public strongly appreciate and recognize it as a valuable material. From pedagogic content knowledge the shift from teaching methodology to guiding methodology, change the way of pure lecture content consumption. Alongside with that, giving more freedom to students in finding the content for getting required knowledge and providing more opportunities for self-study allow to make learning more flexible, with increasing responsibilities of learners.

\subsection{Ideal Final Result}

Application of TRIZ IFR concept leads to the following conceptual models 
- Ideal teaching classroom is lack of the teaching classroom design but knowledge is transferred, experience is gained and attitude is perceived, when it is necessary and where it is necessary

- Ideal lecture is no lecture but the knowledge is transferred and attitude is perceived

- Ideal activities are no activities but the experience is gained and attitude is perceived

The way to ensure the system without its existence can occur if everything happens itself. In that case, there is an idea of completely independent way of study. When students study by themselves, they use huge range of open materials, which include not only passive lectures but also activities. The prepared online courses like MOOCS or combination of different knowledge from video, chats, discussion forum can be used as a teaching materials. Digital technology provided access to the content and online ratings and communication allow stepping in self/study without loss in quality. Pedagogy of self-study emphasis the lowered motivation of students without face-to face activities. In a way, self-study would be more ideal if the environment is a source of stimulation. Consequently, an automotive guide, as your personal teacher, analyses enormous amount of information and selects the learning path, according to your interests and needs. For instance it could be selection of materials by keywords or hashtags. Harmonization of external and internal motivation lead to constant learning and improvement (Table 2. ).

Practically, in Lappeenranta University of Technology, the video lectures were developed using the most-resource effective ways. Thinking, with IFR result, ideal camera is no camera but the function is performed, ideal studio is no studio and etc. For instance, phone instead of special camera and special equipment were used. https://www.youtube.com/channel/UCqr4R5hyHjs1ve-4znD0asQ. In addition, move toward ideality free learning virtual space for students were selected. The videos, quizzes, texts, slides, examples and other materials were gathered on the free-charged platform with open access for unlimited amount of students. http://triz.thinkific.com/courses/triz. The concept of instant feedback system were developed involving IFR. The system according to Ideal Final Result is no system but the questions, comments and mood is transferred to the teacher. The prototype allows students to ask questions without professors' interruption and the questions are posted in the window of presentation, above other windows The one of the versions is published here http://askbox.strikingly.com/ and approached in different classes.

\subsection{Contradictions}

Based on the functional model of "learning design" we can observe the traditional, blended and virtual classroom as a list of contradictions. The list of contradictions is built based on the professors and students' barriers in different classroom types [8, 9, 10] and observations within the Lappeenranta University of Technology environment. Table 1 below consists of contradictions, described by the worsening and improving parameters, inventive principles and generated ideas. Overall, worsening parameters involve 4 main categories: resource related, pedagogical, including instructional designs and evaluation approaches, content and administrative and technological issues. 
For eliminating contradiction, 40 inventive principles were reviewed, selected and adapted for the non-engineering system of classroom design.

Table 1. Contradiction elimination

\begin{tabular}{|c|c|c|c|}
\hline Improving parameter & Worsening parameters & Inventive principles & Solution \\
\hline \multicolumn{4}{|c|}{ Traditional classroom design } \\
\hline $\begin{array}{l}\text { Classroom } \\
\text { digitalization } \\
\text { - Speaking the } \\
\text { same language } \\
\text { with students } \\
\text { Following the } \\
\text { development of } \\
\text { the surrounding } \\
\text { environment } \\
\text { Have a digital } \\
\text { space for } \\
\text { communication }\end{array}$ & $\begin{array}{l}\text { Disturbance of the student's } \\
\text { attention } \\
\text { Learning new skills and } \\
\text { methodologies }\end{array}$ & $\begin{array}{l}\text { Principle } 22 \text { "Blessing in } \\
\text { disguise" or "Turn Lemons } \\
\text { intor Lemonade"(Turn } \\
\text { harmful function into benefit) } \\
\text { Principle 24. 'Intermediary' }\end{array}$ & $\begin{array}{l}\text { Use phones for the } \\
\text { answering a quizzes and } \\
\text { giving feedback rather } \\
\text { for destruction } \\
\begin{array}{l}\text { Use the learning } \\
\text { management system, } \\
\text { video host, social } \\
\text { network for } \\
\text { communication }\end{array}\end{array}$ \\
\hline \multirow[t]{2}{*}{$\begin{array}{l}\text { More free time for } \\
\text { seminars and activities }\end{array}$} & $\begin{array}{l}\text { Class time increase } \\
\text { Increase student workload } \\
\text { Professor' dedicated time } \\
\text { increase } \\
\text { Credits and administration }\end{array}$ & $\begin{array}{l}\text { Principle 1. Segmentation } \\
\text { Principle 2. Taking out } \\
\text { Principle 10. Preliminary } \\
\text { action. }\end{array}$ & $\begin{array}{l}\text { Separate the lecture from } \\
\text { the class by making it } \\
\text { outside the class in the } \\
\text { video form. } \\
\text { Put the lecture before the } \\
\text { class }\end{array}$ \\
\hline & & 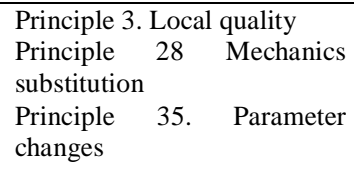 & $\begin{array}{l}\text { Change the object } \\
\text { structure and substitute } \\
\text { the mechanics to digital. }\end{array}$ \\
\hline $\begin{array}{l}\text { Increase student teacher } \\
\text { interaction and student } \\
\text { (personal time, } \\
\text { communities, involvement) }\end{array}$ & $\begin{array}{l}\text { Increased class time (dedicated } \\
\text { time) } \\
\text { Decrease of lecture time (lack } \\
\text { of information) }\end{array}$ & $\begin{array}{l}\text { Principle } 23 \text { Feedback } \\
\text { Principle 32. Color changes }\end{array}$ & $\begin{array}{l}\text { Introduce the feedback } \\
\text { system to improve } \\
\text { lecturing } \\
\text { Use the materials with } \\
\text { the changes color to } \\
\text { involve personality }\end{array}$ \\
\hline \multicolumn{4}{|c|}{ Flipped classroom design } \\
\hline $\begin{array}{c}\text { Introduced video lecture as } \\
\text { a part of flipped classroom } \\
\text { - } \quad \begin{array}{l}\text { Developed by } \\
\text { professors }\end{array} \\
\text { - Selected from } \\
\text { the Internet }\end{array}$ & $\begin{array}{l}\text { Increase of devoted time } \\
\text { Ineffectiveness } \\
\text { Low quality of materials } \\
\text { Not adjustable and } \\
\text { relevant within the selection } \\
\text { Need for new facility and } \\
\text { facility usage }\end{array}$ & $\begin{array}{l}\text { Principle } 5 . \\
\text { principles allow to bring } \\
\text { closer objects } \\
\text { Principle } 25 \text {. Self-service } \\
\text { (make an object serve itself }\end{array}$ & $\begin{array}{l}\text { Find and use lectures and } \\
\text { materials of others } \\
\text { Students search for and } \\
\text { create the materials for } \\
\text { the collection } \\
\text { (Alongside with } \\
\text { learning) }\end{array}$ \\
\hline $\begin{array}{l}\text { Increased amount of video } \\
\text { views before the class }\end{array}$ & $\begin{array}{l}\text { Creating the extra control forms } \\
\text { (like quiz) } \\
\text { Increased time }\end{array}$ & $\begin{array}{l}\text { Principle 6. Universality } \\
\text { Principle 5. Merging }\end{array}$ & $\begin{array}{l}\text { Merge the video part } \\
\text { with questions. The } \\
\text { function of video } \\
\text { become to provide } \\
\text { knowledge and control } \\
\text { their accomplishment. }\end{array}$ \\
\hline Increase the video quality & $\begin{array}{l}\text { Increase of time } \\
\text { Professional training }\end{array}$ & Principle 24. 'Intermediary' & $\begin{array}{l}\text { Involve professionals or } \\
\text { students in the field }\end{array}$ \\
\hline \multicolumn{4}{|c|}{ Online course design } \\
\hline $\begin{array}{l}\text { All materials uploaded on } \\
\text { the online platform }\end{array}$ & $\begin{array}{l}\text { Creating and transition of } \\
\text { materials to new platform }\end{array}$ & Principle 1 Segmentation & $\begin{array}{lr}\text { Connection of already } \\
\text { existing materials in one } \\
\text { open platform rom } \\
\text { Google drives, from } \\
\text { Forms, from } & \text { Social } \\
\text { networks, } & \text { and } \\
\text { Discussion forums } & \\
\end{array}$ \\
\hline $\begin{array}{l}\text { Increase of the } \\
\text { communication with } \\
\text { teacher and increase of } \\
\text { teacher presence in the } \\
\text { virtual }\end{array}$ & $\begin{array}{l}\text { Increased burden on teacher } \\
\text { and time required }\end{array}$ & Principle 15. Dynamics & $\begin{array}{l}\text { Automatic response from } \\
\text { the system }\end{array}$ \\
\hline $\begin{array}{l}\text { Increase of the } \\
\text { communication between } \\
\text { students }\end{array}$ & $\begin{array}{l}\text { Increase of guidance and time } \\
\text { required from teachers }\end{array}$ & Principle 15. Dynamics & $\begin{array}{l}\text { Conditions for the cross } \\
\text { communication }\end{array}$ \\
\hline
\end{tabular}




\begin{tabular}{|l|l|l|l|}
\hline $\begin{array}{l}\text { Increase of the online } \\
\text { platform participation }\end{array}$ & $\begin{array}{l}\text { Increase the time by the amount } \\
\text { of reminders }\end{array}$ & $\begin{array}{l}\text { Principle 35. Parameter } \\
\text { changes } \\
\text { Change the flexibility }\end{array}$ & $\begin{array}{l}\text { Play with flexibility of } \\
\text { the guideline for } \\
\text { Modules opening, } \\
\text { deadlines for modules } \\
\text { Make them more } \\
\text { synchronous or } \\
\text { asynchronous. }\end{array}$ \\
\hline
\end{tabular}

The ideas formulated based on contradictions elimination primarily contribute to improved flipped and virtual classroom conceptual designs. Main pedagogy behind the flipped classroom methodology is freeing time for activities, increasing communication, involvement, personalization and other learning parameters [13]. In addition, structural change allow to make class more flexible adapt it to the different learning styles, familiarize with information beforehand. Therefore, students can get deeper into the materials and gain more practical learning experience. Due to combination of technology and content the lecture part of content, become digitized. The active part can be embed by using feedback system and activities. To increase the time for activities the video part can be separated from the class and mechanics substitution let to transform lecture in a video form. To simplify and improve video materials selection or development the Inventive TRIZ principles lead to ideas of using the materials of others for instance of colleagues. In addition, students can search and add the materials in the collection. In that cases the exercises. In different cases, the video can be developed or selected by professor. Overall, innovative learning designs create more student centered experience.

\subsection{Overview of generated ideas and their implementation}

The ideas and concepts developed with TRIZ method were realised in Lappeenranta University of Technology. The traditional course of "Systematic Creativity and TRIZ basics" was redesigned to partially flipped, flipped and online courses in 2016, 2017, 2018, in accordance. The table 2 presents all learning design ideas generated in the case study, shows applied TRIZ tools and implementation in real courses. Worth mentioning, that the new course design ideas came not solely from TRIZ, but were also based on literature review and practical experiments. Therefore, some of the ideas developed in this case study appear as a repetition of previously embedded design.

Table 2. Ideas and their implementation

\begin{tabular}{|c|c|c|c|}
\hline № & Idea & Generation TRIZ toolkit & Implementation \\
\hline $\mathbf{1}$ & Feedback system & IFR, Contradictions & $\begin{array}{l}\text { Implemented in Partly Flipped course } \\
\text { 2016-2017 }\end{array}$ \\
\hline 2 & $\begin{array}{l}\text { Resource effective video recording } \\
\text { instead of resource required (lean, TRIZ } \\
\text { approaches) }\end{array}$ & IFR & $\begin{array}{l}\text { Implemented for creation video materials } \\
\text { for courses in } 2016\end{array}$ \\
\hline 3 & $\begin{array}{l}\text { Separate the lecture from the class by } \\
\text { making it outside the class in the video } \\
\text { form. }\end{array}$ & $\begin{array}{l}\text { Contradictions } \\
\text { Traditional Design }\end{array}$ & $\begin{array}{l}\text { Implemented from partly-flipped course } \\
2016 \text { to } 2018 \text { online courses }\end{array}$ \\
\hline 4 & $\begin{array}{l}\text { Change the object structure and } \\
\text { substitute the mechanics to digital. }\end{array}$ & & \\
\hline 5 & $\begin{array}{l}\text { Separate the lecture from the class by } \\
\text { making it outside the class in the video } \\
\text { form. }\end{array}$ & & \\
\hline 6 & $\begin{array}{l}\text { Use the materials with the changes color } \\
\text { to involve personality }\end{array}$ & & \\
\hline 7 & Merge the video part with questions & Contradictions & Implemented in flipped classroom 2017- \\
\hline
\end{tabular}




\begin{tabular}{|c|c|c|c|}
\hline & & Flipped classroom & 2018 \\
\hline 8 & $\begin{array}{l}\text { Find and use lectures and materials of } \\
\text { others }\end{array}$ & $\begin{array}{l}\text { Contradictions } \\
\text { Flipped classroom }\end{array}$ & \multirow[t]{4}{*}{ Implemented in online course 2018} \\
\hline 9 & $\begin{array}{l}\text { Play with flexibility of the course temp. } \\
\text { Synchronous /asynchronous }\end{array}$ & $\begin{array}{l}\text { Contradiction } \\
\text { Online course }\end{array}$ & \\
\hline 10 & $\begin{array}{l}\text { Connection of already existing materials } \\
\text { in one } 1 \mathrm{~ms}\end{array}$ & $\begin{array}{l}\text { Contradiction } \\
\text { Online course }\end{array}$ & \\
\hline 11 & $\begin{array}{l}\text { Use the learning management system, } \\
\text { video host, social network for } \\
\text { communication }\end{array}$ & $\begin{array}{l}\text { Contradictions } \\
\text { Traditional Design }\end{array}$ & \\
\hline 12 & MOOCS /online course/ & IFR & $\begin{array}{lrrr}\text { Implemented } & \text { as } & \text { online } & \text { course } \\
\text { developments } 2018 & & \\
\end{array}$ \\
\hline 13 & $\begin{array}{l}\text { Students search for and create the } \\
\text { materials for the collection (Alongside } \\
\text { with learning) }\end{array}$ & $\begin{array}{l}\text { Contradictions } \\
\text { Flipped classroom }\end{array}$ & $\begin{array}{l}\text { Partly implemented in online course } \\
\text { (exercise to share brain-teasers from } \\
\text { students) }\end{array}$ \\
\hline 14 & $\begin{array}{l}\text { Lecture elimination (Flipped classroom } \\
\text { without lecture } \\
\text { a) Substitution lecture with } \\
\text { guidelines and requirements } \\
\text { to activities } \\
\text { Self-study with selection and } \\
\text { learning process guided by } \\
\text { students }\end{array}$ & Trimming & $\begin{array}{l}\text { Not implemented (transformed but not } \\
\text { completely eliminated) }\end{array}$ \\
\hline 15 & Completely independent way of study. & IFR & Not implemented \\
\hline 16 & $\begin{array}{l}\text { An automotive materials selector and } \\
\text { guide }\end{array}$ & IFR & \\
\hline 17 & $\begin{array}{l}\text { Use phones for the answering a quizzes } \\
\text { and giving feedback rather for } \\
\text { destruction }\end{array}$ & $\begin{array}{l}\text { Contradictions } \\
\text { Traditional Design }\end{array}$ & \\
\hline 18 & $\begin{array}{l}\text { Involve professionals or students in the } \\
\text { field }\end{array}$ & $\begin{array}{l}\text { Contradictions } \\
\text { Flipped classroom }\end{array}$ & \\
\hline 19 & Automatic response from the system & $\begin{array}{l}\text { Contradiction } \\
\text { Online course }\end{array}$ & \\
\hline 20 & Conditions for the cross communication & $\begin{array}{l}\text { Contradiction } \\
\text { Online course }\end{array}$ & \\
\hline
\end{tabular}

\subsection{Course designs and implementation roadmap}

The inventive ideas influenced the course redesign for a number of years in which the course was taught. Five different designs of the same course, described in terms of its elements and their description is given in Fig. 5 and Fig.6. Overall, the duration of the course is 78 hours which is equal to 3 credits. From 2011 to 2015 there were practically no significant changes in a course design in terms of structure. The first attempt to re-arrange course took place in the Summer school of 2016. The preparation video materials were developed and integrated. The feedback system was tested. First experience and feedback analysis revealed that the video contents required more control elements and extra preparation materials. The design was enriched by quizzes and other learning materials gathered together on the open elearning platform http://triz.thinkific.com Winter school 2017). However, the students reported the increased overload of materials for relatively short intensive course. In addition, the gap between online and offline environment was revealed: there was no clear navigation between what had been taught in class and presented as selfcontained offline teaching materials.

For Summer school 2017, the flipped classroom model was fully implemented, the video part was realized with embedded questions in EdPuzzle created class and inclass part was activated. The students were randomly grouped in four teams. Each team was supported and mentored by a $\mathrm{PhD}$ student. The teamwork consisted of 
different activities, like generation of ideas, quizzes, games, role changes, cases. To connect the preparation part outside the class and in class part the bridging discussion opened every class day. Pure lecturing part was practically eliminated. According to the observations, surveys and overall experience with course design was the most successful embodiment of flipped classroom (Fig.5).

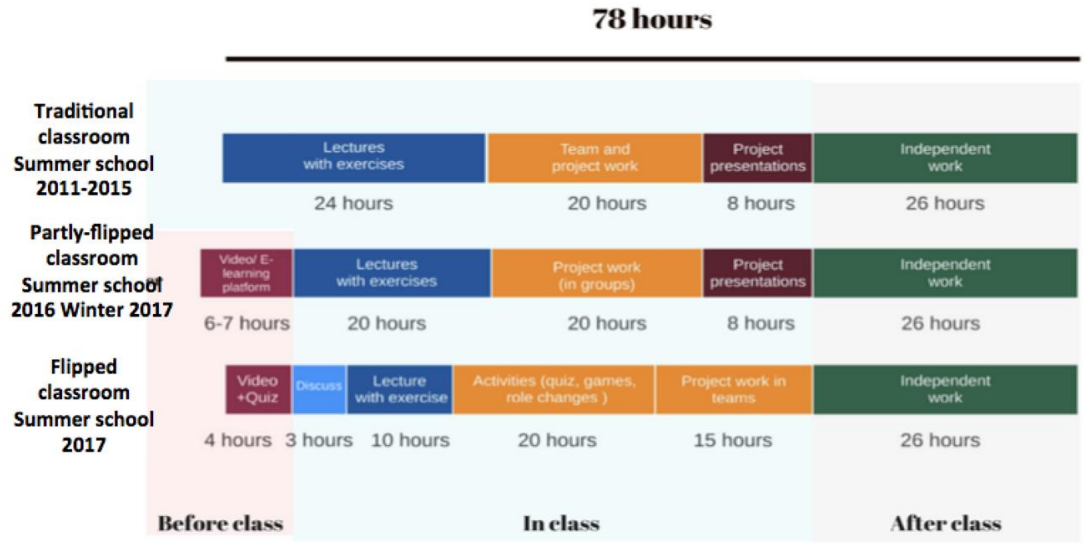

Fig 5. Course designs from Traditional to Flipped

The data was collected through classroom observations, student's questionnaires, scores tracking, specific experiments related to the course content and learning analytics from learning management system, video host, communication channels. Questionnaire forms primarily include the qualitative questions related to students' satisfaction with respect to the design elements. Students feel more involved and motivated with the better understanding. Familiarization with video materials in advance make all students more open for discussion. Involvement of activities within the summer school 2017 provide more benefits. While increased time for activities and 4 mentors, lengthen the personal communication, avoiding free riders in the class. In addition to it, learning analytics from platforms provide an information about possible course design improvements within all the experiments. For, instance the problem of low video watching rate was solved using specifically designed quizzes and in advance shared videos. The main results after each course re-design reveal positive feedback from most of the students [12] and resource-effectiveness of developed flipped classroom design [13].

The last experiments of the same course re-design were conducted during Winter school 2018 (Fig. 6). The session of partly flipped classroom went alongside with online session. The students from partly-flipped classroom 2018 had the same preparation part as flipped 2017 and in class part was the same as partly flipped 2017 (Fig. 5). The online winter school course 2018 started at the same time and was arranged in the separate learning management system triz.thinkific.com. In order to increase student motivation, involvement and to satisfy the needs of the master students, online course mainly consists of activities with the short preparation materials. The online activities involve quizzes to control the video views, discussions related to the topics, assignments, web-meetings and project work with the initial peer- to- peer review. The evaluation of the results is currently in the process. 


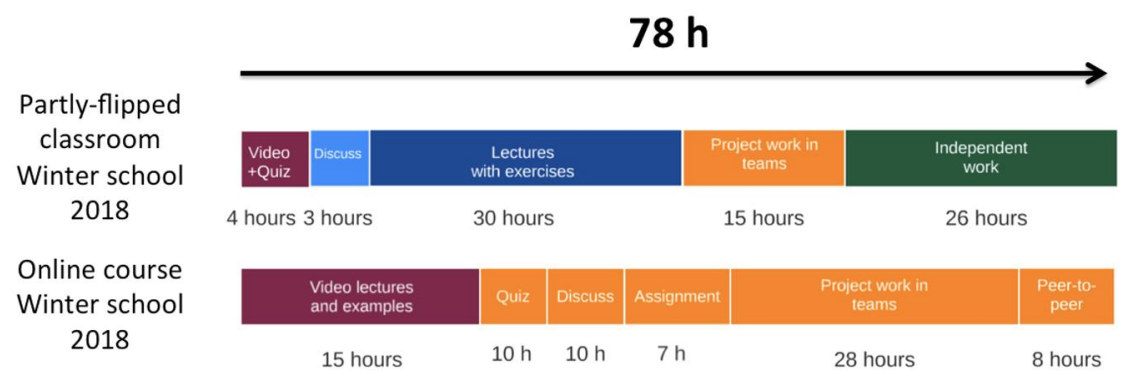

Fig 6. Course designs from Traditional to Flipped

\section{Conclusions}

The paper presents results on application of guided ideation exercise on conceptual redesign of university course. The theory for inventive problem solving, TRIZ, was the main tool for analysis and ideation. The quantitative design ideas were described in the framework of Technological Pedagogical Content Knowledge (TPCK) model The application of new learning concepts was supported by a number of digital tools that could be referred as eLearing. The changes engaged videos and instant feedback system, learning platform development. Several years journey (2016-2018, course "Systematic creativity and TRIZ basics" at Lappeenranta University of Technology) from traditional class organization to flipped classroom and e-learning design is described. The results of students feedback which are described in the previous studies are mentioned and generalised in the chapter. The course in summer school 2017 was the best example of successful flipped classroom design according to the student involvement and satisfaction. The results of the just recently emerged flipped and online classrooms of 2018 are currently in the progress.

\section{References}

1. Bergmann J, Sams A (2012) Flip Your Classroom Reach Every Student in Every Class Every Day. Washington, DC: International Society for Technology in Education

2. Daly S, Yilmaz S, Christian J, Seifert M, Gonzalez R (2012) Design Heuristics in Engineering Concept Generation), Journal of Engineering Education, Vol. 101, No. 4, pp. 601-629

3. Altshuller G, Shapiro R (1956) Psychology of Inventive Creativity. Vopr. Psikhologii (Issues Psychoilogy), no. 6 (1956)

4. Chechurin L, (2016) TRIZ in Science. Reviewing Indexed Publications, Procedia CIRP, Volume 39, Pages 156-165, ISSN 2212-8271, http://dx.doi.org/10.1016/j.procir.2016.01.182.

5. Tucker B (2012). The flipped classroom. Education Next. 12 (1), 82. Retrieved 28/01/2017, from http://educationnext.org/the-flipped-classroom/

6. Mishra P, Koehler M (2006) Technological Pedagogical Content Knowledge: A Framework for Teacher Knowledge Teachers College Record Vol 108, Number 6, , pp. 1017-1054 
7. Shulman L (1987). Knowledge and teaching: Foundations of the new reform Harvard Educational Review, 57(1), 1-22.

8. Antonova N, Shnai I, Kozlova M (2016) Flipped classroom as innovative practice in the higher education system: awareness and attitude, $3^{\text {rd }}$ International Multidisciplinary Scientific Conference on Social Sciences \& Arts SGEM Education\&Educational Research

9. Shnai I (2017) Systematic Review of Challenges and Gaps in Flipped Classroom Implementation: Toward Future Model Enhancement, 16th European Conference on eLearning, School of Business and Management

10. R. Keith Sawyer (2014) The Cambridge Handbook of the Learning Sciences (Cambridge Handbooks in Psychology) University of North Carolina, Chapel Hill

11. Chechurin L, Shnai I (June 2017) Open materials, http://triz.thinkific.com/

12. Shnai I, Chechurin L (2017) Teaching creativity creatively, $28^{\text {th }}$ Australian Association for Engineering Education Conference

13. Shnai I, Kozlova M (2016). Resource and profitability assessment of transition to flipped video-based lecturing European Conference on Technology in the Classroom 2 